Journal of Applied Veterinary Sciences, 5 (4): 25 -36 (2020).

ISSN: Online: 2090-3308, Print: 1687-4072

Journal homepage : https://javs.journals.ekb.eg

\title{
A Focus on Coronaviruses Infections in Animals: Review Article
}

\author{
Shahbaa K. AL-Taee*, Hana Kh.Ismail, Al-Saidya A. M. and Al-sabaawy, H.B. \\ Department of pathology and poultry Diseases, college of veterinary medicine, University of Mosul, Mosul, Iraq. \\ *Corresponding Author, Shahbaa K. AL-Taee, E-Mail: shahbaa_khalil@yahoo.com
}

\begin{abstract}
Coronaviruses are large, enveloped and single-stranded, non-segmented with positive sense RNA virus belong to Nidovirus, family Coronavirirdae and included two subfamilies Orthocoronavirinae and Letovirinae. There are four genera variable in antigenestic characteristic and cross-reactivity (Alpha-coronavirus, Beta-coronavirus, Gamma-coronavirus and Deltacoronavirus) affect mammals and birds while Bafinivirus affect fish and cause different diseases in the vertebrate animals and human, so this review listed most important diseases in some animals which cause economic problems as in the avian cause infectious bronchitis(IB), in the bovine cause diseases in both bowl and respiratory system, Enteric form Disease in the equine, two forms of diseases have been occurred in the feline ( feline enteric coronavirus and feline infectious peritonitis), in canine cause enteric and respiratory syndroms while in the porcine the diseases occur as are Transmissible gastroenteritis virus (TGEV), porcine epidemic diarrhoea virus (PEDV), and porcine deltacoronavirus (PDCoV).Also corona viruses affect aquatic animals and cause general clinical signs in fish. Some of these pathogens transmitted from camel and bates and causes diseases for human as SARS, MERS and SARS-2.From these review the conclusion is the hygiene practices and biosecurity are more important to prevent the emerging diseases in both human and animals cause by coronavirus.
\end{abstract}

Keywords: Animals, Coronaviridae, Coronavirus, PEDV, SARS.

\section{Original Article:}

DOI:https://dx.doi.org/10.21608/javs. $\underline{2020.117997}$

Received :23 July, 2020.

Accepted :29 Aug., 2020.

Published in October, 2020.

This is an open access article under the term of the Creative Commons Attribution 4.0 (CC-BY) International License . To view a copy of this license, visit http://creativecommons.org/licenses/by/4.0/

J. Appl. Vet. Sci., 5(4): $25-36$.

\section{INTRODUCTION}

Coronaviruses (CoVs) are a large family of unsegmented, enveloped, positive sense ssRNA . that infect vertebrate animals and human. CoV causing the nervous, respiratory and digestive systems diseases of humans and other vertebrate (Chen and Guo, 2016; Unhale et al., 2020) as in 2002 disease occur in human called SARS(severe acute respiratory syndrome) and the MERS( Middle East respiratory syndrome) in 2012 ,in these diseases the animals play as intermediat hosts for humans (Cui et al., 2019) also recently coronavirus cause outbreak of severe pneumonia in human the International Committee on Taxonomy of Viruses (ICTV) called about the disease Severe Acute Respiratory Syndrome-Coronavirus-2 (SARSCoV-2) (Lu et al., 2020; Gorbalenya 2020) and then the
World Health Organization (WHO) give its term "COVID-19" (Du Toit 2020; Gralinski and Menachery 2020).

Coronavirus are large, enveloped with protein projections, single stranded RNA related to Nidovirales belong to family Coronaviridae include sub-familyies: Orthocoronavirinae and Letovirinae. The Orthocoronavirinae involve genuses ( Alphacoronavirus, Beta-coronavirus, Gamma-coronavirus and Delta-coronavirus) which could affect mammals and bird and there was phylogenetic branches between these geneses (Fig.1), also there was Bafinivirus which related to Torovirinae and affect fish (International Committee on Taxonomy of Viruses ICTV 2019; de Groot et al., 2012a). Woo et al., (2010) are reported 


\section{A Focus on Coronaviruses Infections in Animals}

the subgenuses involvement in the Beta-coronavirus: Embecovirus, Merbocorvirus, Nobecorvirus and Sarbecorvirus (involve SARS-2).

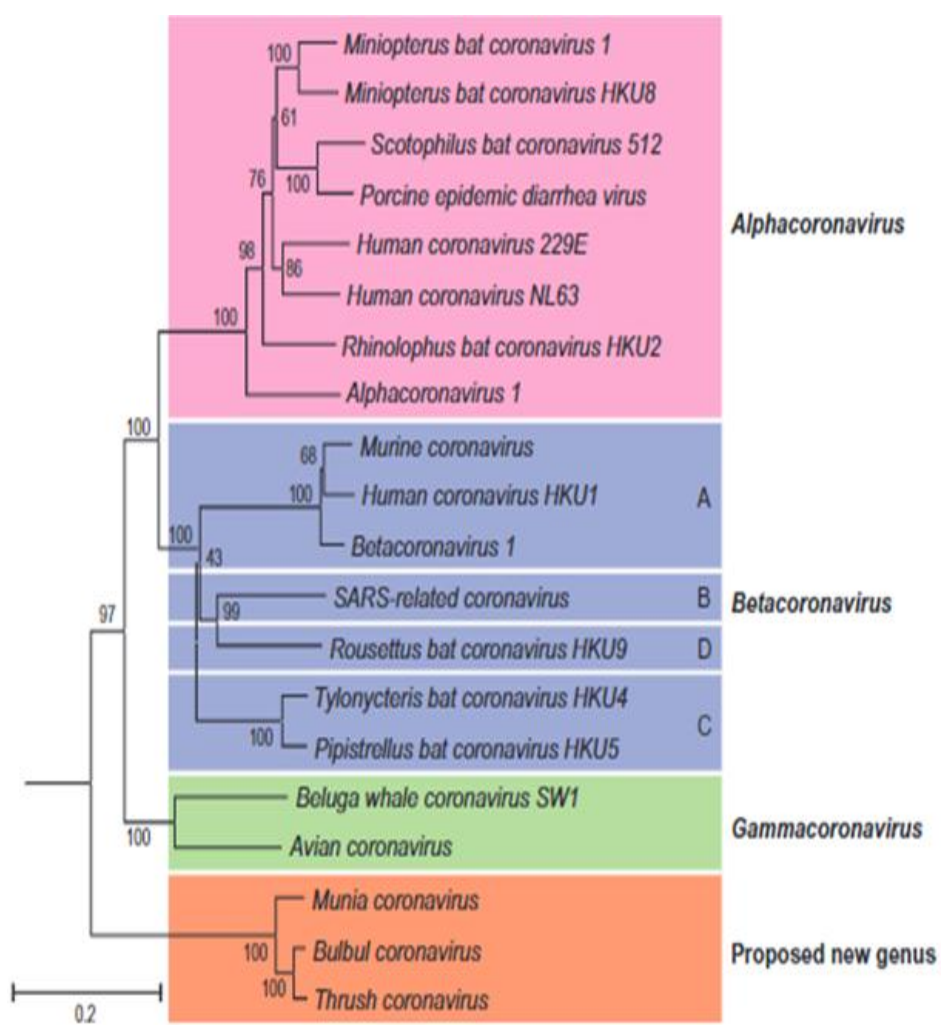

Fig.1: Phylogenetic analysis of geneses of Orthocoronavirinae (ICTV, 2012).

The Viruses was firstly described the nidovirales in 1996 by the International Committee on Taxonomy ,the term coined in 1968, they have spherical in shape $(120-160 \mathrm{~nm})$ in diameters except Bafinivirus have baciliform (150-185 nm), "corona"like or crown-like morphology, all five genera share in some characteristic as they single, positive stranded ribonucleic acid (RNA) approximately $30 \mathrm{~kb}$ with $5^{\prime}$ UTR replicase-SM-NUTR 3' (Lee et al., 2003; de Groot, 2012b), unsegmented, polyadenylated, the structure was polycistronic capped with length 26-32 $\mathrm{kb}$, have helical shape because the genome complexed with the basic nucleocapsid $(\mathrm{N})$ protein also, envelope with large protein projections (80-120 nm),(Fig.2) these envelopes contain numeral variable membrane protein species which are important for binding with host cells ACE2 receptors and cause virion morphogenesis (Belouzard et al.,2012) and infectivity also preserved family -wide ( $\mathrm{S}$ protein which is peplomers ,N-glycosylated and 1100- to 1600 -aa class I fusion protein and triple-spanning NexoCendo integral membrane, 200- to 250-aa protein M 1)and a highly hydrophobic and protein $(\mathrm{E})$ which is slight membrane ( Bond et al., 1979).

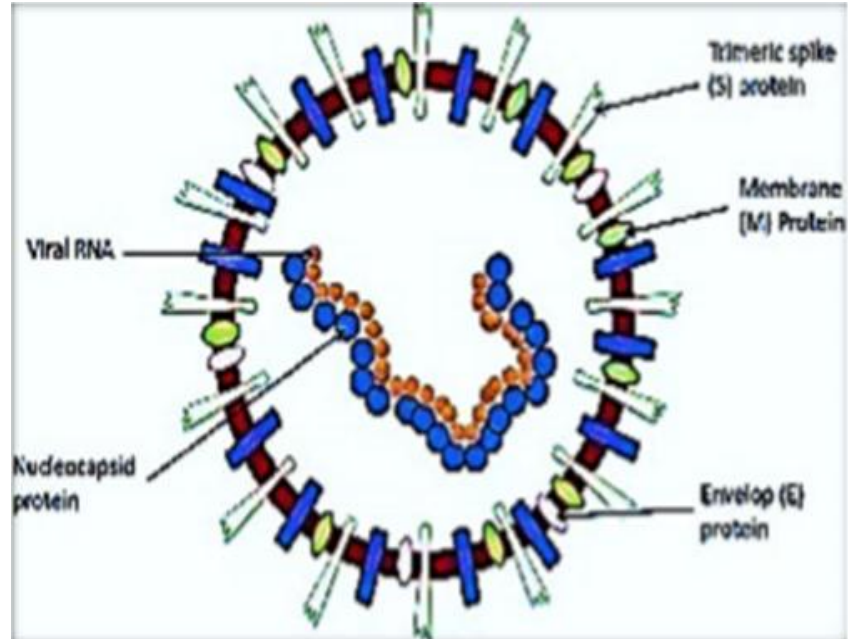

Fig.2: Coronavirus Structure (Meetkamal and Dwivedi,2020)

\section{Coronavirus Diseases in different animal species}

Coronavirinae include genus's variable according to genetic sequence, viral properties these viruses can grouped to animal species infection instead of their classification assignment mainly birds(Avian infectious bronchitis), cattle and horse(Bovine and Equine coronavirus), dog and cat(Feline Peritonitis and Feline enteric coronavirus), coronavirus in porcine, marine and fish coronavirus with laboratory coronavirus.Fig. (1)
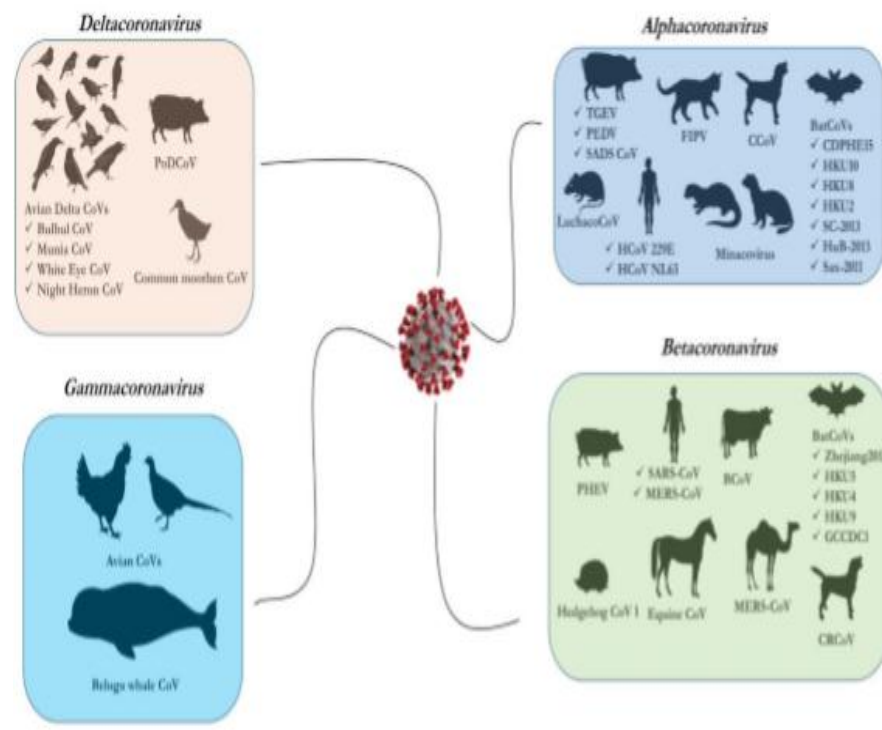

Fig.3: Coronavirusese genus's (Alphacoronavirus, Betacoronavirus, Gammacoronavirus, and Deltacoronavirus) present in human and other as well as avian (Malik et al., 2020) 


\section{Avian Coronavirus (Infectious Bronchitis IB)}

The virus genus's was Gammacoronavirus; it is spread by aerosol so it cause economic losses to the poultry farms through affected respiratory, reproductive and urinary tracts (Dhama et al., 2014). Avain coronaviruses are grouped in to infectious bronchitis (IB) which is highly contiguous disease (Cavanagh, 2007) in chicken and closely genetically related to IBV- like viuses in pheasant and turkey and guinea fowls (Cavanagh, 2005; Weiss and NavasMartin, 2005), it may isolated from wild birds which play vector in epidemelogy and transmitted disease between domestic and wild bird (Milek and BlicharzDomasnska, 2018).

The infectious bronchitis virus was firstly detected in 1930s in United State (Schalk, 1931) and cause economic problem IBV mainly affected epithelial of respiratory tract and may complicated with secondary bacterial and mycoplasma (Meulemans et al., 2002; Matthijs et al., 2003; Landman and Feberwee, 2004) .

This virus infect small aged animals and although it infect the bronchi, it also cause systemic problem as nephritis, cause defect to the oviduct lead to decline in the egg production and infect intestine (Saif, 2004a). Other genus of CoVs are Deltacoroaviruses include White -eye coronavirus HKU16, Muna coronavirus HKU13, Night- heron coronavirus HKU19 and Bulbul coronavirus HKU11 (Paim et al., 2019).

\subsection{Epidemiology and Clinical Signs}

All ages are susceptible to infection with IBV, but small aged birds more susceptible and revealed high mortality and severe respiratory distress (Cook and Mockett, 1995). The period for incubation is take about 18-48hour,the clinical signs variable from moderate to severe diseases according to virulent strain, grading of immune system of the bird at the time of infection on age, and away of contact, dietary aspects (mainly calcium levels in the diet) and the presence of secondary bacterial infection, bad ventilation and decline temperatures all these factors considered as stress. Although primarily affecting the respiratory tract and the clinical signs variable from slight respiratory signs with low rates of both morbidity and mortality to severe respiratory distress characterized by wheezing, nasal exudate, coughing, sneezing, lacrimation and other respiratory disturbances with sinusitis.

In young chicks mortality is generally $25-30 \%$, and may reach to $75 \%$ in cases of outbreak. Also, the virus may be infect oviduct of young female chickens and led to reduction in eggs product as a result of cellular growth disturbances of the oviduct (Fan $\boldsymbol{e t}$ al., 2018). IBV demonstrates a varied tropism range for tissues, including the kidney and oviduct (Cavanagh, 2007 and Bande et al.,2016).

\subsection{Pathogenesis}

The virus has a high affinity and firstly replicates in the ciliated epithelial cells of respiratory system; then viremia occur through 1-2 days of infection, in which virus spread to variable organs include the gastrointestinal, genetal and urinary tracts. The pathogenesis of the disease variable according to the virus strain and system involved (Cavanagh, 2007).

\section{Bovine Coronavirus (Beta Coronavirus)}

BCoVs are mainly infect the intestinal and respiratory tracts of healthy cattle and diarrheic calves, in 1973 they were original stated in the United as a reason of diarrhea in calves, the diseases has including three clinical syndromes, respiratory infections with shipping fever, winter dysentery occur in adult and in small age animals the diseases called calf diarrhea in all age cattle the diseseas are universal implications (Suzuki et al.,2020). Antigenically similar have been determined for both viruses cause enteric and respiratory distress in cattle (Saif, 2004b; Fulton et al., 2015and Gomez, 2017). In addition to infected domestic ruminant with Bovine -like coronaviruses the wild ruminants may also diseased with these viruses (Amer, 2018; Kim et al., 2018).

\subsection{Epidemiology and Clinical Signs}

Two main factors affecting the wide spread distribution of $\mathrm{BCoV}$ : (1) the virus spread through via fecal-respiratory and oral routes (Decaro et al.,2008) and (2)The feces of carriers animals considered as source for the virus mainly during stress environmental as cold period and parturition which represented the source of infection for neonatal.

The BOVs diseases occur in two forms, Enteric $\mathrm{BCoV}$ infection cause disease in both dairy and beef calf at early three weeks of aged and cause calf diarrhea (Boileau and Kapil, 2010), while in adult dairy cattle the virus cause winter dysentery lead to decline in milk production (Natsuaki et al., 2007). The main investigation clinical signs of NCD was watery or yellow diarrhea, sometimes mixed with mucus or blood, is observed, lasting between 2 - 6 days with weakness and dehydration. Shipping fever occur in feedlot calve aged 2-16 weeks with respiratory problems (Saif, 2010), nasal and lachrymal discharge are the main signs of upper respiratory tract infection, while bronchopneumonia represented the sign of lower 
respiratory tract infection, which may be associated with enteric forms of the disease. The severity of the clinical signs in NCD varies according to the level of maternal antibodies ingested by the calf which are usually occur after 5 days of age, when the level of virus-specific colostrum-derived antibodies decreases dramatically in the digestive tract.

\subsection{Pathogenesis}

The epithelial cells in the lung, trachea, and nasal turbinate's and enterocytes in the distal small and large intestines are chief positions of $\mathrm{BCoV}$ duplication (Park et al., 2007). Other reports have documented that the virus shedding through two way, from respiratory tract after replication in the oropharynx or shedding with feces after swallowing the virus with mucus and reached to the stomach and intestine (Thomas et al., 2006). A high viral load in the environment caused by a large number of animals excreting virus could probably also be a direct source of infection for the digestive tract.

\section{Equine Coronavirus (Enteric Diseases, Beta coronavirus)}

\subsection{Epidemiology and Clinical Signs}

The ECoVs are disease mainly characterized by diarrhea which occur as sporadic, mild cases in horses, the severe cases are rare and mainly affect young age animals, the ECoVs is firstly isolat in outbreaks from enteric disease in the US in 1991 also in Japan in 2011from old aged horses (Guy et al., 2000; Pusterla et al., 2013 and Kooijman et al., 2017).

The infection occurs through oral exposure and ingested feed and water contaminated with fecal, the incubation period was 48-72 hour and begin shedding the virus after 3-4 days of exposure (Pusterla et al., 2018) the beta coronavirus that infect the equine lack the affinity to epithelial cell of respiratory tract and shedding the virus from nasal discharge is limited rather than the disease occur in cattle as two forms(enteric and respiratory) (Pusterla et al., 2015). The morbidity ranges from $10-83 \%$ and the clinical signs were lethargy, fever, mild colic and neurological abnormalities the mortality range is rare and occur as a result of secondary infection and barrier damage of gastrointestinal tract and cause endotoxemia and septicemia with elevated concentration of ammonia in the blood a combined with encephalopathy (Pusterla et al., 2018).

\section{Feline Coronaviruses (Alphacoronaviruses) 4.1.Epidemiology and Clinical Signs.}

The coronaviruses cause disease in feline in two forms Feline enteric coronavirus $(\mathrm{FeCoV})$ is the causes of enteric disease which happen as benign and infect respiratory and central nervous system which lead to death and infectious peritonitis (FIP) (Jaimes and Whittaker, 2018; Tekes and Thiel, 2016). Faces are the main source of transmission the FCoV, while the inhalation, saliva even transplacental transmission are very rare (Addie and Jarrett, 2001). In 1963 the feline infectious peritonitis was described as lethal, a common advanced and debilitating disease in both wild and domestic feline more common occur in depress immune status in all aged. Two forms of the disease will be occur(1) non-effusive(dry) form characterized by forming granuloma lesions with pus in the tissues (2) effusive (wet) form characterized by inflammation of blood vessels and accumulation fluid in the chest and abdomen (Kipar et al., 2005).

There is a scientific agreement that the genetic mutation in S gene of FECVs lead to form FIPVs in the same environment and alters the tropism for macrophage (Harley et al., 2013 and Rottier et al., 2005), replication of FIPV begin in the bowel, respiratory and pharyngeal epithelial cells and travel the lymph nodes after tropism and infected macrophages more replication would be occur in the lymph nodes then spread to the organs and cause viremia which lead to nervous and ocular distress with inflammation of the thoracic and abdominal cavities (Addie, 2004).

\section{Canine Coronaviruses}

The disease was firstly reported in 1971 in German dogs, the CoVs occur in two genotype alphacoronavirus cause enteric syndrome $(\mathrm{CCoV})$ was similar to transmissible gastroenteritis (TGVE) (Perlman and Netland, 2009) and beta-coronavirus cause respiratory syndrome (CRCoV) (Licitra et al., 2014) which is similar to BoCoVs and describe in 2003 as respiratory illness called Kennel cough because injury to the ciliated respiratory epithelium (Erles $\boldsymbol{e t}$ al., 2007; Szczepanski et al., 2019).

There is other classification according to tissue tropism as entertropic cause maldigesation and malabsorption because destruction of enterocyte and intestinal villi and pantropic which the virus affect kidney, spleen, liver and CNS and the disease characterized by leukopenia, depression, diarrhea, anorexia, vomiting (Buonavoglia et al., 2006).

\section{Porcine Coronavirus}

There are several porcine CoVs that are include Transmissible gastroenteritis virus (TGEV), porcine epidemic diarrhea virus (PEDV), and porcine delta coronavirus (PDCoV), Swine acute diarrhea (SADs-CoV) and hemagglutinating encephalomylities virus (PHEV), the variable stage and severity of porcine coronavirus describe as in Fig. (2). 


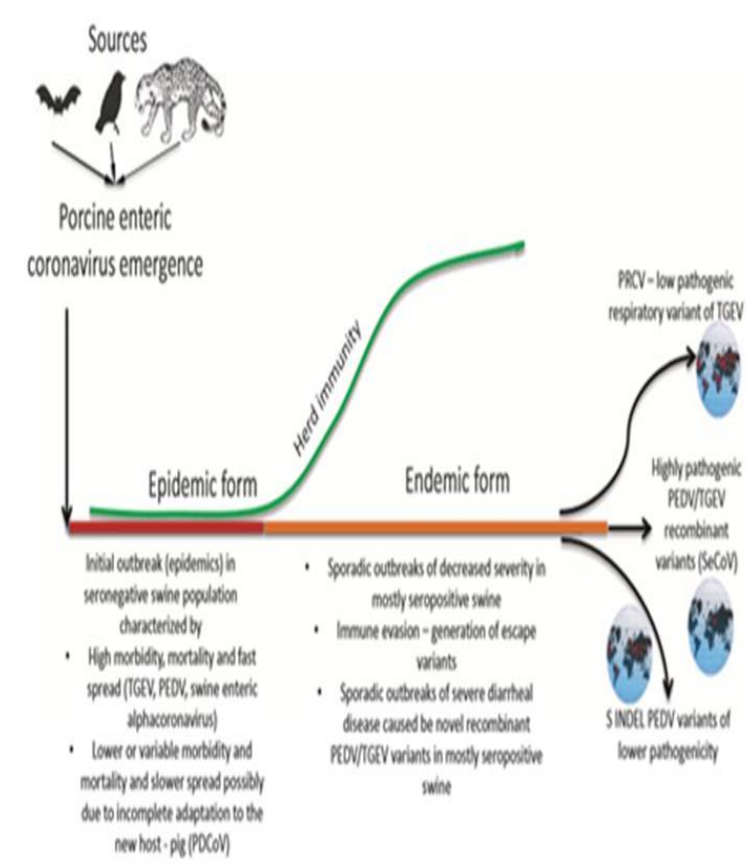

Fig.4: Variable phases of esstimation of coronavirus as enteric disease in swine ( Vlasova et al., 2020)

\subsection{Pathogenesis and Clinical Signs \\ 6.1.1.Transmissible gastroenteritis (TGVE)}

It is worldwide spread disease was firstly described in 1946 as an extremely infectious disease occur as enteric forms in the swine (Weiss and NavasMartin,2005). Virus replication and targets the absorpative epithelial cells of villi and cause villous atrophy and severe necrosis to enterocyte of ileum and jejunum during twenty four hour after exposure to pathogen lead to disturbances in the enzyme activity, digestion and imbalance electrolytes led to accumulated the fluid in the lumen of the intestine , severe malabsorptive diarrhea(Moon et $\boldsymbol{a l . , 1 9 7 5}$ and Wu et al.,2020) severe TGVE are more common in small aged piglets and death uncommon after aged 2-3 weeks, the disease symptoms involved copious yellow watery diarrhea, vomiting, dryness and fast loss of body weight, vomiting animals was unusual but main clinical signs is the watery diarrhea, the upper respiratory tract may often affect(Enjuanes $\boldsymbol{e t}$ al., 1995).

\subsection{2.porcine respiratory virus (PRVC)}

PRCV is coronvirus that have been tropism and duplication in the pneumocyte type 1 and 2 and is isolated from epithelial cells of the upper and lower respiratory tract and seen in the alveolar macrophage(Atanasova et al.,2008), it can isolate from blood and tracheobronchial lymph nodes, it transmitted through mucus shedding the virus after 4-6 day of infection. The main clinical signs are lung and broncho interstitial pneumonia perivascular lymph histiocytic handcuffing (Jung et al., 2007 and Atanasova et al., 2008).

\subsection{3. porcine epidemic diarrhea virus (PEDV)}

Is a viral enteritis and a common in pigs cause high mortality rates in neonatal piglet, it was firstly identified and describe in the 1970s in Europe, in April 2013in US the PEDV was occur as largest outbreaks with high mortality (Oldham, 1972 and Lee, 2015). The infection with PEDV occur through digestive and inhalation and take 1-4 days as incubation period, clinically similar with like pathogenesis of TGVE with it variation in the slower spread with in the herd association with low mortality (Sun et al., 2012; Song et al., 2015 and Lin et al., 2019), in very small aged piglet it causes vomiting, severe diarrhea, dehydration with high death rates and the diarrhea without vomiting are the main disease symptoms in a fattening growing pigs .

\subsection{4. porcine delta coronavirus (PDCoV)}

Delta coronaviruses is a new developing pathogen initially described in Hong Kong in 2012 (Woo et al., 2012a) as diarrhea in neonatal piglets, and spread to other countries including china, Thailand and United State (Zhao et al. 2019; Saeng-chuto et al., 2020 and Koonpaew et al., 2019), it take 1-3 day as incubation period and cause mild disease rather than other porcine coronavirus and the mortality rate reach to 40\% during outbreak, (Ma et al., 2015 and Jung et al., 2016). PDCoV replicates and tropism to epithelial cell of the small and large intestine and lead to loss of enterocyte and cause malabsorption and the clinical signs similar to theTGVE and PEDV (Chen et al. 2015; Hu et al. 2016) The clinical signs of the disease represented by watery, acute, diarrhea, vomiting, loss body fluid, weight loss, lethargy and death, among suckling pigs mortality reach up to $40-80 \%$ (Anon 2014).

\subsubsection{Swine acute diarrhea (SADs-CoV):}

The disease detected in piglet in China as alphacoronavirus, cause enteritis and death, there was a sequence analysis similarity of SADs-CoV to bats (horseshoe) about 95-96\% and was called KHU2-CoV (Zhou et al., 2018).

\subsubsection{Porcine hemagglutinating encephalomyelitis virus (PHEV): \\ This virus is described in 1962 and classified} as coronavirus in 1971, affected nervous and digestive system (Greig et al., 1962; Clarke and McFerran, 1971), (Mora-Diasnet al. 2019). Early reported about the PHEV as neurotropic properties in pigs affected all age but cause high morbidity and mortality in piglets below four weeks age also, the disease occur as subclinical (Mora-Diasn et al. 2019). 


\section{A Focus on Coronaviruses Infections in Animals}

\section{Aquatic Organisms}

7.1.Marine organisms

In 1987, Alphacoronvirus was firstly isolated from dead habor seals (Phoca vitulina) in Miami Sea aquarium and describe the disease as acute necrotizing enteritis (Bossart and Schwartz, 1990). A novel [BWCoV-SW1] is Gamma-coronavirus detected in 2008, was isolated by panviral microarray technology from hepatic tissue of white beluga whale (Delphinapterus leucas) (Mihindukulasuriya et al., 2008), also bottlenose dolphin CoVs (BdCoV)HKU22 was detected and isolated o from the fecal samples of bottlenose dolphins(Tursiops aduncus), both BWCoVSWI and BdCoV HKU22) are named Cetacean coronavirus (Woo et al., 2014).

\subsection{Freshwater fish}

In Germany, bacilliforms, bafinivirus white bream virus (WBV) has been isolated from healthy $(B$. bjoerkna L.) (Granzow et al., 2001). Also, in 1997 the virus was initial identification from diseased moribund fathead minnows ( $P$. promelas) and called Fathead Minnow Virus (FHMNV) exhibited hemorrhage on the skin and eyes, in addition to renal ,splenic and hepatic lesion, this pathogen considered second genus present in the Bafinivirus (Iwanowicz and Goodwin, 2002; Batts et al., 2012).

\section{Camels Coronavirus}

In Saudi Arabia in 2012 the diseased camels considered intermediated host for the Middle East respiratory syndrome (MERS) which is caused by coronavirus $(\mathrm{CoV})$ and can transmitted to human cause fatality rate about of 35\% (Hawkes, 2013).

\section{Bat coronavirus}

Coronoaviruses infected bats are (alpha and beta), which is considered reservoirs for $\mathrm{CoV}$ and asymptomatic carrier (Fan et al., 2019) that cause diseases in human and animals include severe acute respiratory syndrome (SARS), Middle East respiratory syndrome (MERS), porcine epidemic diarrhea (PED) and severe acute diarrhea syndrome (SADS), (Banerjee et al., 2019).

\section{Zoonotic of Coronavirus}

Coronaviruses have genus's (alpha-cov, beta- cov, gamm-cov and delta-cov) with twenty six species and there was cross-reactivity and genetic closely related with some of them (Paules et al., 2020), although $\mathrm{CoVs}$ consider veterinary microb but the genera alpha$\mathrm{CoV}$ and beta $-\mathrm{CoV}$ have been affected human for at least many century ago and initiated in animals and bats(Chan et al., 2013), alpha-CoV cause endemic mild respiratory illness (HCoV-229, HCOV-OC43, HCoV-NL63 and HCoV-HKU1) and the disease of beta $-\mathrm{CoV}$ called epidemic severe acute respiratory syndrome SARS and middle east respiratory syndrome MERS(Skariyachan et al., 2019).
All $\mathrm{CoV}$ are originated from animal reservoir and transmitted from bats, mice, and domestic animals but there was limited zoonotic diseases transmitted from human to human (Weber et al., 2001 and Cotton et al., 2013) Fig. (5).

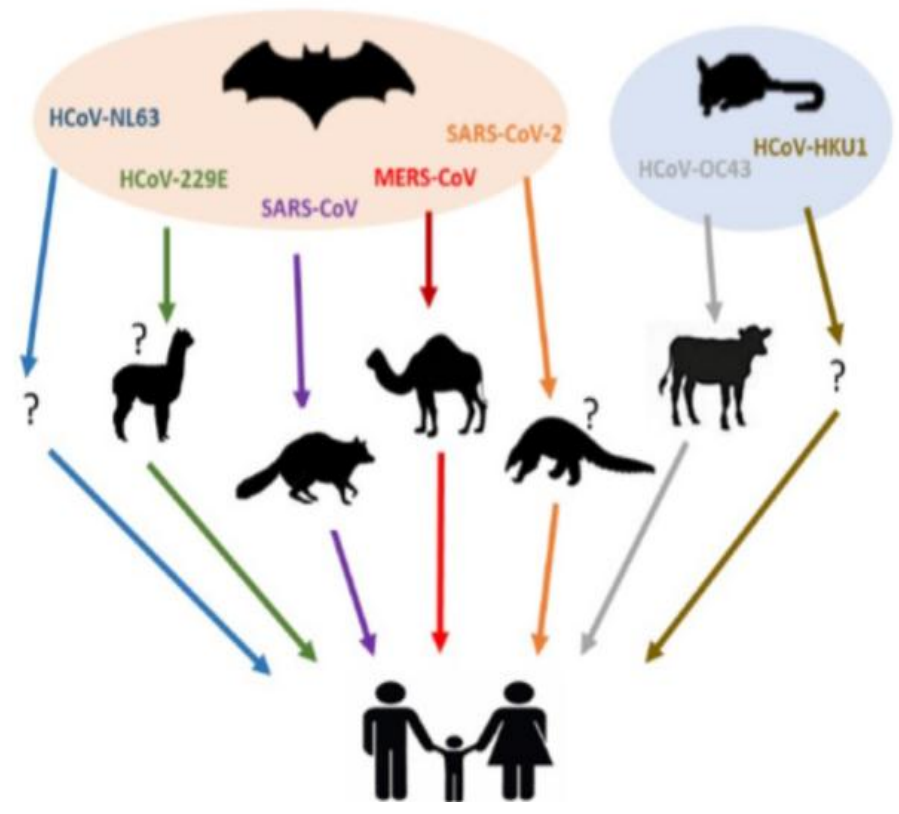

Fig.5: Origin of human CoVs and intermediated host (Ye et al., 2020)

Anovel CoV cause SARS (a typical pneumonia) was firstly reported in China Provins in 2002and then spread to Europe, Asia and North America (Peiris et al., 2003; Chen et al., 2007). Guan et al.,(2003) suggested that racoon dogs and masked palm civets (Paguma laravata) are carrier for SARS, also horseshoe bats transmitted this disease (Ge et al., 2013; Fan et al., 2019). While epidemic MERS is reported in 2012 in Saudia Arabia, the disease transmitted through direct contact with disease dromedary camels and consumption milk and meat of illness camels(Durai et al., 2015 and Aleanizy et al., 2017).

Recently, in December of 2019 severe, cough, dyspnea and fetal pneumonia have been detected beginning in Seafood Market in Wuhan City in China, the disease called pandemic SARS-2 because it spread to worldwide with high mortality rate (Huang $\boldsymbol{e t}$ al., 2019), SARS-2 is less pathogenic than SARS and MERS but more and raped transmissible spread (Ye $\boldsymbol{e t}$ al., 2020), animals considered origin as other $\mathrm{CoV}$ and intermediated host for human then transmitted between human(Hui et al., 2020; Nishiura et al., 2020). Bats (Rhinolopus affinis) is the origin of SARS-2 (Zhou et al., 2020b), in addition recent study suggested that Malayan pangolin (Manis javanica) play role as intermediated host for SARS-2(Lam et al.,2019 and Xiao et al., 2020). 
Is SARS-2 has been reversible transmitted from human to animals?

Although that SARS-2 was origin from animals but there was variable susceptibility between the them (OIE, 2020), Shi et al., (2020) reported result about the poorly SARS-2replication in the chicken, dog, pig and ducks rather than ferret and cat, these efficient replication may due to similarity to human by possessing ACE2 receptors (Anderson et al., 2020).

A few newly reports evidence that SARS-2 may transmitted from human to pet animals and cause mild respiratory illness (Malik et $\boldsymbol{a l}$., 2020), recent knowledge for SARS-2 transmitted from human to animals was firstly reported in April, 2020 in which tiger called Nadia housed in Bronx zoo in New York show sneezing and dry cough with positive result for SARS-2 which transmitted from illness keeper house with SARS-2.

\section{COVID-19 and Animals}

Also the infection reported in pet dogs and cats United State, Hong Kong and Belgium, all these cases were direct contact with the infected owners but the clinical signs in these animals variable in severity from non- symptoms disease to mild respiratory syndrome with recovery status for all cases(Islam, 2020), many studies should be done in future to understand the mechanism of the pathogen transmitted from the human to the animals.

In general raped diagnosis coronavirus and SARS-2 in both human and animals play an important roles to prevent spread infection and these will take traditional diagnostic methods as antigen detection and cell culture, ELISA, Immunofluorescence and more specific diagnosis methods depend on RT-PCR and genome sequence(Minakshi et al., 2020). The prevention is efficiently than usage drug and therapy methods so the hygein and biosecurity are more important to preventing the disease.

\section{CONCLUSIONS}

Coronavirus have been detected s emerging pathogen cause sporadic and outbreak diseases in animals and human as SARS-1, MERS and SARS-2 which are zoonotic diseases transmitted from animal to human.Recent disease SARS-2 has revirsable transmittion from human to pet animals, so it is important to make framework of biosecurity hygiene to protect human and animals from pathogen.

\section{REFERENCES}

ADDIE, D. D. 2004. Feline coronavirus - that enigmatic little critter. Vet. J. 167:5-6. DOI: 10.1016/s10900233(03)00083-2.

ADDIE, DD, AND JARRETT, O. 2001. Use of a reversetranscriptase polymerase chain reaction for monitoring feline coronavirus shedding by healthy cats Vet Rec. 148: 649-53. doi: 10.1136/vr.148.21.649.

ALEANIZY, F.S., MOHMED, N., ALQAHTANI, F.Y .AND MOHAMED, R.A.E. 2017. Outbreak of Middle East. BMC Infectiuos Disesaes. 17:23 DOI 10.1186/s12879-016-2137-3.

AMER, H. M. 2018. Bovine-like coronaviruses in domestic and wild ruminants. Animal Health Research Reviews 19(2): 113-24. doi.org/10. 1017/S 146625 2318000117

ANDERSON, K.G., RAMBAUT,A.,LIPKIN， W.L., HOLMES,E.C.,GARRY, R.F.2020. The Proximal originof SARS-CoV-2.Nat Med 26(4):450-452. doi: 10.1038/s41591-020-0820-9.

ANON.2014. USDA to require reports of PED. J Am Vet Med Assoc 244:1234.

ATANASOVA, K., VAN GUCHT, S., BARBÉ, F., LEFEBVRE, D.J., CHIERS, K., VAN REETH, K. 2008. Lung cell tropism and inflammatory cytokineprofile of porcine respiratory coronavirus infection. Open Vet Sci J 2:117-126. doi: 10.2174/ 1874318800802010117

ATANASOVA, K., VAN GUCHT S., BARBÉ, F.,LEFEBVRE, D.J., CHIERS, K. ,VAN REETH, K. 2008. Lung cell tropism and inflammatory cytokine-profile of porcine respiratory coronavirus infection. Open Vet Sci J 2:117-126. doi: 10.2174/1874318808002010117.

BANDE, F., ARSHA, S.S, OMAR, A.R., BEJO, M.H, ABUBAKAR, MS, ABBA,Y . 2016. Pathogenesis and Diagnostic Approaches of Avian Infectious Bronchitis. Adv Virol 2016: 4621659. Doi: 10.1155 /2016/4621659.

BANERJEE, A, KULCSAR, K., MISRA, V., FRIEMA, M., MOSSMAN, K. 2019. Bats and Coronaviruses Viruses .11(41) :1-15. doi:10.3390/v11010041 www.mdpi.com/journal/viruses.

BATTS, W.N., GOODWIN, E.A, WINTON, J.R. 2012. Genetic analysis of a novel nidovirus from fathead minnows. Journal of General Virology 93, 1247-1252 DOI 10.1099/vir.0.041210-0.

BELOUZARD, S., MILLET, J.K., LICITRA, B.N., WHITTAKER, G.R.2012. Mechanisms of coronavirus cell entry mediated by the viral spike protein. Viruses. 2012;4:1011-33. https:// doi.org/10.3390/v4061011

BOILEAU, M.J., KAPIL, S. 2010. Bovine coronavirus associated syndromes.Veterinary Clinics of North America: Food Animal Practice 26, 123-146. DOI: 10.1016/j.cvfa.2009.10.003.

BOND, C. W., LEIBOWITZ, J. L., ROBB, J. A. 1979. Pathogenic murine coronaviruses. II. Characterization of virus-specific proteins of murine coronaviruses JHMV and A59V. Virology 94:371-384. DOI: 10.1016/0042-6822(79)90468-9. 
BOSSART, GD., SCHWARTZ, J.C. 1990. Acute necrotizing enteritisassociated with suspected coronavirus infection in three harbor seala (Phoca vitulina). J.Zoo.Wildl.Med 21:84-87.

BUONAVOGLIA, C., DECARO, N., MARTELLA, V., ELIA, G., CAMPOLO, M., DESARIO, C., CASTAGNARO, M., TEMPESTA, M. 2006. Canine coronavirus highly pathogenic for dogs. Emerging Infectious Diseases 12(3): 49. doi: 10.3201/eid 1203. 050839

CAVANAGH, D. 2005. Coronavirus in poultry and other birds.Avain Pathology 34(6).439-448. doi:10.1080/030.

CAVANAGH, D. 2007. Coronavirus avian infectious bronchitis virus Veterinary Research, vol. 38, no. 2, pp. 281-297. Doi:10 .1051/ vetres :2006055

CHAN, J.F., TO, K.K., TSE, H., JIN, D.Y., YUEN, K.Y.2013. Interspecies transmission and emergence of novel viruses: lessons from bats and birds. Trends Microbiol 21: 544-55. doi: 10.1016/j.tim.2013.05.005.

CHEN, Y., GUO, D. 2016. Molecular mechanisms of coronavirus RNA capping and methylation. Virol. Sin 31, 3-11. Doi: 10.1007/s12250-016-3726-4.

CHENG, V.C., LAU, S.K., WOO, P.C., YUEN, K.Y. 2007. Severe acute respiratory syndrome coronavirus as an agent of emerging and reemerging infection. Clin Microbiol Rev 20: 660-94. doi: 10.1128/ CMR.00023-07.

CLARKE, J., MCFERRAN, J. 1971. An electron microscopic study of haemagglutinating encephalomyelitis virus of pigs. Journal of General Virology 13(2): 339-44. doi: 10.1099/0022-1317-132-339.

COOK, J. K. A., MOCKETT, A. P. 1995. Epidemiology of infectious bronchitis virus, p. 317-336. In S. G. Siddell (ed.), The Coronaviridae. Plenum Press, New York, N.Y.

COTTON, M., WATSON, S.J., KELLAM, P., ALRABEEAH, A.A., MAKHDOOM, H.Q., ASSIRI, A., AL-TAWFIQ, J.A., ALHAKEEM, R.F., MADANI, H., ALRABIAH, F.A., AL HAJJAR, S., AL-NASSIR, W.N., ALBARRAK, A., FLEMBAN, H., BALKHY, H.H., ALSUBAIE, S., PALSER, L.A., GALL. A., BASHFORD-ROGERS, R., RAMBAUT, A., ZUMLA, A.I., MEMISH, Z.A. 2013. Transmission and evolution of the Middle East respiratory syndrome coronavirus in Saudi Arabia: a descriptive genomic study. Lancet.;382:1993-2002. doi: 10.1016/S0140-6736

CUI, J., LI, F., SHI, Z.L. 2019. Origin and evolution of pathogenic coronaviruses. Nat. Rev. Microbiol 17, 181-192. DOi: 10.1038/s41579-018-0118-9.

DE GROOT, R.J., BAKER, SC, BARIC, R., ENJUANES, L., GORBALENYA, A.E., HOLMES, K.V., PERLMAN, S., POON, L., ROTTIER, P. J. M., TALBOT, P.J.,WOO P.C.Y., ZIEBUHR, J. 2012a. Family coronaviridae. In:King,A.M.Q., Adams M.J.,Carstens E.B., Lefkowitz E.J.(Eds),Virus Taxonomy, Classification and Nomenclautre of Viruses.Ninth Report of the International Committee onTaxonomy of Viruses Elsevier Academic Press, San Diego, CA,pp.806-828.

DE GROOT, R.J., BAKER, SC, BARIC, R., ENJUANES, L., GORBALENYA, A.E.,
HOLMES, K.V., PERLMAN, S., POON, L., ROTTIER, P. J. M., TALBOT, P.J.,WOO P.C.Y., ZIEBUHR, J. 2012b. Order nidovirales. In:King, A.M.Q., Adams M.J.,Carstens E.B., Lefkowitz E.J.(Eds), Virus Taxonomy, Classification and Nomenclautre of Viruses.Ninth Report of the International Committee onTaxonomy of Viruses Elsevier Academic Press, San Diego, CA,pp.785-795.

DECARO, N., CAMPOLO, M., DESARIO, C., CIRONE, F. D., ABRAMO, M., LORUSSO, E., GRECO, G., MARI, V., COLAIANNI, M.L., ELIA, G., MARTELLA, V., BUONAVOGLIA, C.2008. Respiratory disease associated with bovine coronavirus infection in cattle herds in Southern Italy. J Vet Diagn Invest 20:28-32. doi: 10.1177/104063870802000105.

DHAMA, K., SINGH, S. D., RAJAMANI, B., DESINGU, P., SANDIP C., RUCHI, T. , KUMAR, M. 2014. Emergence of avian infectious bronchitis virus and its variants need better diagnosis, prevention and control strategies: a global perspective. Pakistan Journal of Biological Sciences 17(6): 751-67. doi: 10.3923/pjbs.2014.751.767.

DU TOIT, A. 2020. Outbreak of a novel coronavirus. Nature reviews Microbiology 18(3): 123-23. doi: 10.1038/s41579-020-0332-0.

DURAI, P., BATOOL, M., SHAH, M., CHOI, S.2015. Middle East respiratory syndrome coronavirus: transmission, virology and therapeutic targeting to aid in outbreak control. Exp Mol Med 47: e181. https://www.nature.com/articles/emm201576

ENJUANES, L., SMERDOU, C., CASILLA, J., ANTÓN, I.M., TORRES, J.M., SOLA, I., GOLVANO, J., SÁNCHEZ, J.M., PINTADO, B. 1995. Development of protection against coronavirus induced diseases. In Corona-and Related Viruses pp 197-211. Springer

ERLES, K., SHIU, K.B., BROWNLIE, J. 2007. Isolation and sequence analysis of canine respiratory coronavirus. Virus Research 124(1-2): 78-87. doi: 10.1016/j.virusres.2006.10.004

FAN, WS, LI, HM, HE, Y.N., TANG, N., ZHANG, L.H., WANG, H.Y., ZHONG, L., CHEN, J.C., WEI, T.C., HUANG,T. 2018. Immune protection conferred by three commonly used commercial live attenuated vaccines against the prevalent local strains of avian infectious bronchitis virus in southern China. Journal of Veterinary Medical Science 80(9): 143844. DOI: 10.1292/jvms.18-0249.

FAN, Y., ZHAO, K., SHI, Z.L., ZHOU, P. 2019. Bat Coronaviruses in China. Viruses 11(3): 210. doi: 10.3390/v11030210

FULTON, R.W., HERD, H.R.,SORENSEN, N., CONFER, A.W., RITCHEY, J.W., RIDPATH, J.F., BURGE, L.J. 2015. Enteric disease in pos tweaned beef calves associated with Bovine coronavirus clade 2. Journal of Veterinary Diagnostic. Investigation 27, 97.doi:10.1177/1040638714559026.

GE, XY, LI, J.L., YANG, X.L., CHMURA, A.A., ZHU ,G., EPSTEIN ,J.H., MAZET, J.K.,HU ,B., ZHANG, W., PENG, C., ZHANG, Y.J., LUO, C.M., TAN, B., WANG, N., ZHU, Y., CRAMERI, G., ZHANG, S.Y., WANG, L.F., DASZAK ,P., SHI 
,Z.L.2013. Isolation and characterization of a bat SARS-like coronavirus that uses the ACE2 receptor. Nature. 503:535-8. doi: 10.1038/nature12711.

GOMEZ, D.E., ARROYO, L.G, POLJAK, Z., VIEL, L., WEESE,J.S. 2017. Detection of Bovine Coronavirus in Healthy and Diarrheic Dairy Calves. J Vet Intern Med ,31(6): 1884-1891. doi: 10.1111/jvim.14811.

GORBALENYA, A. E. 2020. Severe acute respiratory syndrome-related coronavirus-The species and its viruses, a statement of the Coronavirus Study Group. BioRxiv 2020.02.07.937862: 1-15.doi: 10.1101/ 2020.02.07.937862

GRALINSKI, L. E., MENACHERY, V. D. 2020. Return of the Coronavirus: 2019-nCoV. Viruses 12(2): 135. doi: 10.3390/v12020135.

GRANZOW, H., WEILAND, F., FICHTNER, D., SCHU“TZE, H., KARGER, A., MUNDT, E., DRESENKAMP, B., MARTIN, P., METTENLEITER, T. C. 2001. Identification and ultrastructural characterization of a novel virus from fish. J Gen Virol 82, 2849-2859. doi: 10.1099/00221317-82-12-2849.

GREIG, A., MITCHELL, D., CORNER, A., BANNISTE, G., MEADS, E., JULIAN R. 1962. A hemagglutinating virus producing encephalomyelitis in baby pigs. Canadian Journal of Comparative Medicine and Veterinary Science 26(3): 49. https://www.ncbi.nlm.nih.gov/pmc/ articles/PMC1583410/pdf/vetsci00064-0003.pdf

GUAN, Y., ZHENG, B.J., HE, Y.Q., LIU, X.L., ZHUANG, Z.X., CHEUNG, C.L., LUO, S. W., LI, P.H., ZHANG, L.J., GUAN, Y.J., BUTT ,K.M., WONG ,K.L., CHAN, K.W., LIM, W., SHORTRIDGE, K.F., YUEN, K.Y., PEIRIS, J.S.M, POONISOLATION, L.L.M.2003. Isolation and characterization of viruses related to the SARS coronavirus from animals in Southern China. Science 302:276-9. doi: 10.1126/science.1087139.

GUY, J.S., BRESLIN, J.J., BREUHAUS, B., VIVRETTE, S., SMITH, L. G. 2000. Characterization of a coronavirus isolated from a diarrheic foal. Journal of Clinical Microbiology 38(12): 4523-2. https://www.ncbi.nlm.nih. gov/pmc/ articles/PMC87631/

HARLEY, R., FEWS,D., HELPS,C.R. ,SIDDELL, S.G.2013. Phylogenetic analysis of feline coronavirus strains in an epizootic outbreak of feline infectious peritonitis.Journal of Veterinary Internal Medicine 27:445-450. doi: 10.1111/jvim.12058.

HAWKES N. 2013. Camels could be the source of MERS coronavirus, research finds. BMJ 347: f5052.

HU, H., JUNG, K, VLASOVA, AN ET AL 2016. Experimental infection of gnotobiotic pigs with the cell- culture- adapted porcine deltacoronavirus strain OH-FD22. Arch Virol 161:3421-3434. doi: 10.1007/s00705-016-3056-8.

HUANG, C., WANG, Y., LI, X., REN, L., ZHAO, J., HU, Y., ZHANG, L., FAN, G., XU, J.,GU, X., CHENG, Z., YU, T., XIA, J., WEI ,Y., WU, W., XIE, X., YIN, W., LI, H., LI ,M., XIAO, Y.,GAO, Z., JIN, Q., WANG, J., CAO, B .2020. Clinical features of patients infected with 2019 novel coronavirus in
Wuhan, China. Lancet. doi.org/10.1016/S01406736(20)30183-5

HUI, D. S. I., AZHAR, E., MADANI, T.A., NTOUMI ,F., KOCK, R., DAR, O., IPPOLITO, G., MCHUGH, T. D., MEMISH, Z .A., DROSTEN, C. 2020. The continuing 2019-nCoV epidemic threat of novel coronaviruses to global health-The latest 2019 novel coronavirus outbreak in Wuhan, China. International Journal of Infectious Diseases 91: 264-66.

INTERNATIONAL COMMITTEE ON TAXONOMY OF VIRUSES (ICTV).2019. https://talk.ictvonline. org/ictvreports/ictv_9th_report/positive-sense-rnaviruses-2011/w/posrna_viruses /222/ coronaviridae. (Accessed 25 May 2020).

INTERNATIONAL COMMITTEE ON TAXONOMY OF VIRUSES.2012. Virus Taxonomy: Ninth Report of the International Committee on Taxonomy of Viruses Published by Elsevier Inc. All Rights Reserved. https://reader.elsevier.com/reader/sd/pii/.

ISLAM, M.I.2020. COVID-19 and Pet Animals: What we need to know? Res. Agric. Livest. FisH 7(1):83-86. DOI: https://doi.org/10.3329/ralf.v7i1. 46834.

IWANOWICZ, L.R., GOODWIN, A.E.2002. A new bacilliform fathead minnow rhabdovirus that produces syncytia in tissue culture. Arch.Virol 147:899-915. doi: 10.1007/s00705-001-0793-z.

JAIMES, J.A., WHITTAKER, G. 2018. Feline coronavirus: Insights into viral pathogenesis based on the spike protein structure and function. Virology 517:108-121. doi: 10.1016/j.virol. 2017.12.027.

JUNG, K., HU, H., SAIF, L. J. 2016. Porcine deltacoronavirus infection: etiology, cell culture for virus isolation and propagation, molecular epidemiology and pathogenesis. Virus Research 226: 50-59. doi: 10.1016/j.virusres.2016.04.009

JUNG, K., ALEKSEEV, K.P.,ZHANG, X.CHEON, D.S., VLASOVA, AN, SAIF, LJ 2007. Altered pathogenesis of porcine respiratory coronavirus in pigs due to immunosuppressive effects of dexamethasone: implications for corticosteroid use in treatment of severe acute respiratory syndrome coronavirus. J Virol 81:13681-13693. doi: 10.1128/JVI.01702-07.

KIM, J. H., JANG, J.H., YOON, S.W., NOH, JY, AHN, M.J., KIM, Y., JEONG, D. G., KIM, H. K. 2018. Detection of bovine coronavirus in nasal swab of non-captive wild water deer, Korea. Transboundary and Emerging Diseases 65(3): 627-31. DOI: 10.1111/tbed.12847

KIPAR, A., MAY, H., MENGER, S.,WEBER, M.,LEUKERT, W. , REINACHER, M.; 2005. Morphologic features and development of granulomatous vasculitis in feline infectious peritonitis. Vet Pathol.; 42: 321-30. DOI: 10.1354/vp.42-3-321

KOOIJMAN, L.J., JAMES, K.,MAPES, S.M., THEELEN, M.J.1., PUSTERLA, N. 2017. Seroprevalence and risk factors for infection with equine coronavirus in healthy horses in the USA. The Veterinary Journal. 220: 91-94. doi: 10.1016/j.tvj1.2017.01.007.

KOONPAEW, S., TEERAVECHYAN, S., FRANTZ, N., CHAILANGKARN, T., JONGKAEWWATTANA, A. 2019. PEDV and 
PDCoV pathogenesis: the interplay between host innate immune responses and porcine enteric coronaviruses. Frontiers in Veterinary Science 6: 34. doi.org/10.3389/fvets.2019.00034

LAM, T, SHUM, M., ZHU, H., TONG, Y., NI, X., LIAO, Y., WEI,W., CHEUNG, W.Y.M., WEN- LI ,J., LI ,L.F., LEUNG, G.M., HOLMES, E.C., HU ,Y.L., GUAN ,Y.2020. Identification of 2019-nCoV related coronaviruses in Malayan pangolins in southern China. BIORXIV. doi: 10.1101/2020.02.13.945485.

LANDMAN, W.J.M., FEBERWEE, A. 2004. Aerosolinduced Mycoplasma synoviae arthritis: the synergistic effect of infectious bronchitis virus infection. Avian Pathology 33, 591 -598. doi.org/10. 1080/030794504000 13170

LEE, C. 2015. Porcine epidemic diarrhea virus: an emerging and re-emerging epizootic swine virus. Virology Journal 12(1): 193. doi: 10.1186/s12985-015-0421-2

LEE, N., HUI, D., WU, A., CHAN, P., CAMERON, P., JOYNT, G.M,AHUJA, A.,YUNG, M.Y,LEUNG, C.B, TO, K.F,LUI, K.F, SZETO, C.C,CHUNG, S. ,SUNG, J.J. 2003. A major outbreak of severe acute respiratory syndrome in Hong Kong. N. Engl. J. Med. 348:1986-1994. DOI: 10.1056/NEJMoa030685.

LICITRA, B. N, DUHAMEL, G. E., WHITTAKER, G.R. 2014. Canine enteric coronaviruses: emerging viral pathogens with distinct recombinant spike proteins. Viruses 6(8): 3363-7. doi: 10.3390/v6083363

LIN, C.M., GHIMIRE, S., HOU, Y., BOLEY, P., LANGEL, S.N., VLASOVA, A. N., SAIF, L. J., WANG, Q. 2019. Pathogenicity and immunogenicity of attenuated porcine epidemic diarrhea virus PC22A strain in conventional weaned pigs. BMC Veterinary Research 15(1): 111. doi.org/10.1186/s12917-0181756-X

LOMNICZI, B. J. 1977. Biological properties of avian coronavirus RNA. Gen. Virol. 36:531-533.Doi: 10.1099/0022-1317-36-3-531.

LU, H., STRATtON, C. W., TANG, Y. W. 2020. Outbreak of Pneumonia of Unknown Etiology in Wuhan China: The Mystery and the Miracle. Journal of Medical Virology 92: 401-02. https://doi.org/10.1002/jmv.25678

MA, Y., ZHANG, Y., LIANG, X .ET AL 2015. Origin, evolution, and virulence of porcine deltacoronaviruses in the United States. MBio 6: e00064. DOI: 10.1128/mBio.00064-15

MALIK,Y.S., SHUBHANKAR, SIRCAR, S., BHAT, S. OR V., TIWARI, R., SAH, R., RABAAN, A.A., RODRIGUEZ-MORALES, A.J. , DHAMA, K. 2020. Emerging Coronavirus Disease (COVID-19), a pandemic public health emergency with animal linkages: Current status update. Preprints (www.preprints.org) | NOT PEER-REVIEWED | Posted: 23 March 2020, doi:10.20944/ preprints202003. 0343.v1.

MATTHIJS, MGR, VAN ECK, J.H.H., LANDMAN, W.J.M., STEGEMAN, J.A. 2003. Ability of Massachusetts-type infectious bronchitis virus to increase colibacillosis susceptibility in commercial broilers: a comparison between vaccine and virulent field virus. Avian Pathology, 32, 473 -481.

https://doi.org/10.1080/0307945031000154062.
MEETKAMAL AND DWIVEDI, R.K.2020. Study of Morphological Nature of Coronavirus: Causes and Prevention. J Pure Appl Microbiol 14(suppl 1):963970. https://doi.org/10.22207/JPAM.14.SPL1.34.

MEULEMANS, G., VAN DEN BERG, T.P., DECAESSTECKER, M., BOSCHMANS, M. 2002. Evolution of pigeon Newcastle disease virus strains. Avian Pathology.31, 515 519. doi.org/10.1080/ 0307945021000005897

MIHINDUKULASURIYA, K. A., G. WU, J. ST. LEGER, R. W. NORDHAUSEN ，D. WANG .2008. "Identification of a Novel Coronavirus from a Beluga Whale by Using a Panviral Microarray." Journal of Virology 82(10): 5084-5088. DOI: 10.1128/jvi.02722-07

MILEK, J., BLICHARZ-DOMASNSKA, K. 2018. Coronaviruses in Avain species -review with focus on epidemiology and diagnosis in wild birds. J Vet Res 62:249-255.Doi: 10.2478/jvetres-2018-0035.

MINAKSHI, P., RANJAN2 ,K., BRAR,B., AMBAWAT, S., SHAFIQ,M., ALISHA1,A., KUMAR,P., GANESHA RAO,J.V., JAKHAR1, S., BALODI,S., SINGH,A., PRASAD,G.2020. New Approaches for Diagnosis of Viral Diseases in Animals. Advances in Animal and Veterinary Sciences 2 (4S): $55-63$.

http://dx.doi.org/10.14737/journal.aavs/2014/2.4s.55.63.

MOON, H.W.; KEMENY, L.J., LAMBERT, G. 1975. Age-dependent resistance to transmissible gastroenteritis of swine. III. Effects of epithelial cell kinetics on coronavirus production and on atrophy of intestinal villi. Vet Pathol 12:434-445. doi: 10.1177/0300985875012005-00610.

MORA-DÍAZ, J.C., PIÑEYRO, P. E., HOUSTON, E., ZIMMERMAN, J., GIMÉNEZ-LIROLA, L. G. 2019. Porcine Hemagglutinating Encephalomyelitis Virus: A Review. Frontiers in Veterinary Science 6(53):1-1. doi.org/10.3389/fvets.2019.00053

Natsuaki, S., Goto, K.,Nakamura, K., Yamada, M.,UEO, H.; KOMORI, T.; SHIRAKAWA, H., UCHINUNO, Y. 2007. Fatal winter dysentery with severe anemia in an adult cow. Journal of Veterinary Medical Sciences 69, 957-960. doi: 10.1292/jvms.69.957.

NISHIURA, H., LINTON, N.M., AKHMETZHANOV AR. 2020. Initial cluster of novel coronaviruses (2019-nCoV) infections in Wuhan, China is consistent with substantial human-to-human transmission. Journal of Clinical Medicine 9(2): 488. doi: $10.3390 /$ jcm 9020488 .

Oldham J. 1972. Letter to the editor. Pig Farming 10: 72-7.

WORLD ORGANIZATION FOR ANIMAL HEALTH OIE. 2020.INFECTION WITH SARS-COV-2 IN ANIMALS. \{ Accessed 2020 July 3$\}$.

https://www.oie.int/fileadmin/Home/MM/A_Factsheet_SAR S-CoV-2 1.pdf.

PAIM, F.C., BOWMAN, A.S., MILLER, L., FEEHAN, B. J., MARTHALER, D., SAIF, L. J. , VLASOVA, AN. 2019. Epidemiology of Deltacoronaviruses $(\delta$ $\mathrm{CoV})$ and Gammacoronaviruses $(\gamma \mathrm{CoV})$ in Wild Birds in the United States. Viruses 11(10): 897. https://www.mdpi.com/1999-4915/11/10/897/pdf

PARK, S.J.,KIM, G.Y.,CHOY, H.E., HONG, Y.J.,SAIF, L.J., JEONG, J.H.,PARK, S.I., KIM, H.H.,KIM, 
S.K., SHIN, S.S., KANG, M.I., CHO, K.O. 2007. Dual enteric and respiratory tropisms of winter dysentery bovine coronavirus in calves. Arch Virol.,152(10):1885-900. DOI: 10.1007/s00705-0071005-2.

PAULES, C.I.,MARSTON, H.D.,FAUCI, A.S. 2020. Coronavirus infections-More than just the common cold. ;323(8):707-708. doi:10.1001/jama.2020.0757 https://jamanetwork.com/journals/jama/fullarticle/275 $\underline{9815 .}$.

PEIRIS, J.S., LAI ,S.T., POON, L.L., GUAN, Y., YAM, L.Y., LIM, W., ET AL. 2003. Coronavirus as a possible cause of severe acute respiratory syndrome. Lancet. 361: 1319-25. doi: 10.1016/s01406736(03)13077-2.

PERLMAN, S., NETLAND, J. 2009. Coronaviruses postSARS: update on replication and pathogenesis. Nature reviews Microbiology 7(6): 439-50. doi: 10.1038/nrmicro2147.

PUSTERLA, N., MAPES, S., WADEMAN, C., WHITE, A., BALL, R., SAPP, K., BURNS, P., ORMOND, C., BUTTERWORTH, K., BARTOL, J. 2013. Emerging outbreaks associated with equine coronavirus in adult horses. Veterinary Microbiology 162(1): 228-31. doi: 10.1016/j.vetmic.2012.10.014

PUSTERLA, N., HOLZENKAEMPFER, N.,MAPES, S. , KASS, P. 2015. Prevalence of equine coronavirus in nasal secretions from horses with fever and upper respiratory tract infection. Veterinary Rec., 19;177(11):289. doi: 10.1136/vr. 103263.

PUSTERLA, N., VIN, R., LEUTENEGGER, C,C.M. ,MITTELD, L.D. , DIVERS, T.J. 2018. Enteric coronavirus infection in adult horses. Vet J., 231: 1318 doi: 10.1016/j.tvj1.2017.11.004

ROTTIER, P. J., NAKAMURA, K., SCHELLEN, P., VOLDERS, H., HAIJEMA, B J. 2005. Acquisition of macrophage tropism during the pathogenesis of feline infectious peritonitis is determined by mutations in the feline coronavirus spike protein. Journal of Virology 79(22): 14122-30. doi: 10.1128/JVI. 79. 22. 14122-14130.2005.

SAENG-CHUTO, K., JERMSUTJARIT, P., STOTT, C.J., VUI, D.T., TANTITUVANONT, A., TRANSBOUNDARY, DNJ, DISEASES, E. 2020. Retrospective study, full-length genome characterization and evaluation of viral infectivity and pathogenicity of chimeric porcine deltacoronavirus detected in Vietnam. Transbound. Transbound Emerg. Dis., 67(1):183-198. doi: 10.1111/tbed. 13339.

SAIF, L.J. 2004a. Animal coronavirus vaccines: lessons for SARS. Dev. Biol. 119:129-140. doi: 10.20506/ rst.23.2.1513

SAIF, L. J. 2004b. Animal coronaviruses: what can they teach us about the severe acute respiratory syndrome? Rev. Sci. Technol 23:643-660. doi: 10.20506/ rst.23.2.1513

SAIF, LJ 2010. Bovine respiratory coronavirus. Veterinary Clinics of North America: Food Animal Practice 26,349-364. Doi: 10.1016/j.cvfa.2010.04005

SCHALK, A. 1931. An apparently new respiratory disease of baby chicks. Journal of the American Veterinary Medical Association 78: 413-23.
SHI, J.,WEN, Z., ZHONG, G., YANG, H., WANG, C., HUANG, B., LIU, R., HE, X., SHUAI, L., SUN, Z., ZHAO, Y., LIU,P., LIANG, L., CUI, P., WANG ,J.,ZHANG, X., GUAN ,Y., GUIZHEN,W., WU ,T., CHEN,H., BU,Z.2020. Susceptibility of ferrets, cats, dogs, and other domesticated animals to SARScoronavirus 2. Science. 8:eabb7015. doi: 10.1126/science.abb7015.

SKARIYACHAN, S., CHALLAPILLI, S.B., PACKIRISAMY, S., KUMARGOWDA， S.T., SRIDHAR, V.S.2019. Recent aspects on the pathogenesis mechanism, animal models and novel therapeutic interventions for middle east respiratory syndrome coronavirus infections.10:569. doi: 10.3389/fmicb.2019.00569.

SONG, D., MOON, H., KANG, B. 2015. Porcine epidemic diarrhea: a review of current epidemiology and available vaccines. Clin Exp Vaccine Res.,4:166176.Doi:10.7774/cevr.2015.4.2.166.

SUN, R.Q.,CAI, R.J.,CHEN, Y.Q., LIANG, P.S., CHEN, D.K. ,SONG, CX. 2012. Outbreak of porcine epidemic diarrhea in suckling piglets China. Emerg Infect Dis., 18:161-3. DOI: 10.3201/eid1801.111259

SUZUKI, T., OTAKE, Y., UCHIMOTO, S., HASEBE, A., GOTO, Y. 2020. Genomic Characterization and Phylogenetic Classification of Bovine Coronaviruses Through Whole Genome Sequence Analysis. Viruses 12(2): 183. doi: 10.3390/v12020183

SZCZEPANSKI, A., OWCZAREK, K., BZOWSKA, M., GULA, K., DREBOT, I., OCHMAN, M., MAKSYM, B., RAJFUR, Z., MITCHELL, J.A., PYRC, K. 2019. Canine Respiratory Coronavirus, Bovine Coronavirus, and Human Coronavirus OC43: Receptors and Attachment Factors. Viruses 11(4): 32. doi: 10.3390/v11040328

TEKES, G. AND THIEL H-J. 2016. Feline coronaviruses: pathogenesis of feline infectious peritonitis. In Advances in Virus Research, pp 193-218. Elsevier. doi: 10.1016/bs.aivir. 2016.08.002

THOMAS, C.J., HOET, A.E., SRIVATSA, S., WITTUM, T.E.,BRIGGS, R.E., DUFF, G.C. ,SAIF, LJ 2006. Transmission of bovine coronavirus and serologic responses in feedlot calves under field conditions. Am J Vet. Res,67 (8): 1412-20. doi: 10.2460/ajvr.67.8.1412.

UNHALE, SS,ANSAR, Q.B., SANAP, S.,THAKHRE, S.,WADATKAR, S., BAIRAGI, R.,SAGRULE, S. ,BIYANI, K.R. 2020. A review on corona virus (COVID-19). World Journal of Pharmaceutical. 6:109-115.

VLASOVA, A.N., WANG, Q., JUNG, K., LANGEL, S.N., MALIK, Y.S., SAIF LJ 2020. Porcine Coronaviruses. Emerging and Transboundary Animal Viruses.79-110. doi: 10.1007/978-981-15-0402-0_4.

WEBER, D.J., RUTALA, W.A. 2001.Risks and prevention of nosocomial transmission of rare zoonotic diseases. Clin Infect Dis 32:446-56.

WEISS, S. R., NAVAS-MARTIN, S. 2005. Coronavirus pathogenesis and the emerging pathogen severe acute respiratory syndrome coronavirus. Microbiology and Molecular Biology Reviews 69(4): 635-64. doi: 10.1128/MMBR.69.4.635-664.2005. 
WOO, P.C., HUANG, Y., LAU, S.K., YUEN, K.Y.2010. Coronavirus genomics and bioinformatics analysis. Viruses 2(8):1804-20. doi: 10.3390/v2081803.

WOO, P.C., LAU, S. K., BAI, R., TENG, J. L., LEE, P., MARTELLI, P., HUI, S.W , YUEN, K.Y. 2012. Complete genome sequence of a novel picobirnavirus, otarine picobirnavirus, discovered in California sea lions. Journal of Virology 86(11): 6377-78. doi: 10.1128/JVI.00686-12.

WOO, P.C.Y, LAU, S.K.P, LAM, C.S.F, TSANG, A.K.L, HUI, S.W., FAN, R.Y.Y, MARTELLI, P., YUEN, K.Y. 2014. Discovery of a novel bottlenose dolphin coronavirus reveals a distinct species of marine mammal coronavirus in gammacoronavirus. J. Virol 88,1318-1331. DOI: 10.1128/JVI.02351-13.

WU, A., YU, B., ZHANG, K., XU, Z., WU, D., HE, J., LUO, J., LUO, Y., YU, J. , ZHENG, P. 2020. Transmissible gastroenteritis virus targets Paneth cells to inhibit the self-renewal and differentiation of Lgr5 intestinal stem cells via Notch signaling. Cell Death \& Disease 11(1): 1-16. DOI: $10.1038 / \mathrm{s} 41419$ 020-2233-6

XIAO, K., ZHAI ,J., FENG, Y., ZHOU, N., ZHANG, X., ZOU, J.J, LI, N., GUO, Y., LI, X. ,SHEN, X. 2020. Isolation and Characterization of 2019-nCoV-like CoronavirusfromMalayan.1-31.

https://www.biorxiv.org/content/10.1101/2020.02.17. 951335v1.full.pdf

YE, Z.W., YUAN, S., YUEN, K.S., FUNG, S.Y., CHAN, C.P., , JIN, D.Y.2020. Zoonotic origins of human coronaviruses. International Journal of Biological Sciences 16(10): 1686-1697. doi: 10.7150/ijbs.45472.

ZHAO, Y.; QU, H.; HU J.; FU, J.; CHEN, R.; LI, C.; CAO S.; WEN Y.; WU,R.; ZHAO,Q.; YAN, Q.; WEN, X. AND HUANG, X.2019. Characterization and Pathogenicity of the Porcine Deltacoronavirus
Isolated in Southwest China.Viruses. 11, 1074; doi:10.3390/v11111074.

ZHOU P, FAN H, LAN T, YANG X-L, SHI W-F, ZHANG W, ZHU Y, ZHANG Y-W, XIE Q-M AND MANI S. 2018. Fatal swine acute diarrhoea syndrome caused by an HKU2-related coronavirus of bat origin. Nature 556(7700): 255-58. doi: 10.1038/s41586-018-0010-9.

ZHOU P, YANG $X$, WANG $X$, HU B, ZHANG $L$, ZHANG W, SI H, ZHU Y, LI B AND HUANG C, CHEN HD, CHEN J, LUO Y, GUO H, JIANG RD, LIU MQ, CHEN Y, SHEN XR, WANG X, ZHENG XS, ZHAO K, CHEN QJ, DENG F, LIU LL, YAN B, ZHAN XF, WANG YY, XIAO GF, SHI ZL. 2020. A pneumonia outbreak associated with a new coronavirus of probable bat origin. Nature 579: 270-73doi: 10.1038/s41586-020-2012-7.

How to cite this article:

Shahbaa K. AL-Taee, Hana Kh.Ismail, Al-Saidya A. M. and Al-sabaawy, H.B.2020. A Focus on Coronaviruses Infections in Animals: Review Article.Journal of Applied Veterinary Sciences, 5(4): $25-36$.

https://dx.doi.org/10.21608/javs.2020.117997 